\title{
On the Naming of Arctic Archaeological Traditions: The Case for Paleo-Inuit
}

For archaeologists, the consistent application of names for ancient cultures is central to productive academic communication; when one of us uses a term such as "Late Dorset," we need to know that our colleagues understand that this refers to a specific society bounded in space and time, with a particular set of characteristics. Thus, we tend to be conservative in our terminology, shying away from changing the names of the cultures we deal with. However, the naming of past cultures also has implications for how the public, and in particular the descendants of the archaeological cultures we study, understand the past, each other, and us.

In the eastern North American Arctic, consisting of the Canadian Arctic Archipelago, adjacent mainland areas, and Greenland, archaeologists have defined a cultural sequence that, at its core, is quite simple. Two major traditions exist (the term "tradition," sometimes but not always capitalized, is used to label well-defined, geographically extensive, and long-lasting units; it can usually be used interchangeably with the terms "culture" and "period"). The earlier tradition, lasting from around $3200 \mathrm{BC}$ to shortly after AD 1300, is generally called "PaleoEskimo," with alternative spellings including "Palaeoeskimo" and "Paleoeskimo." The original term, coined by Steensby (1916), was spelled "Palæeskimo." Its earliest half is sometimes called the "Arctic Small Tool tradition," but it is now commonly simplified to "Early Paleo-Eskimo." After about AD 1200, people of the second tradition, bearing a completely new culture, arrived from Alaska. The archaeological tradition of which they were a part is usually called "Eskimo," "Neo-Eskimo," "Northern Maritime," or "Thule." These were the direct ancestors of all modern Inuit, Inuvialuit, and Iñupiat across the Arctic.

Over the past several decades, there has been a growing awareness that the term "Eskimo" is not appropriate in many contexts. Most fundamentally, it is a name given to Inuit by outsiders rather than a self-designation, and it has come to be considered pejorative in some, though certainly not all, contexts. As a result, many archaeologists now term the most recent archaeological tradition "Inuit," rather than "Neo-Eskimo" or the like, even though there hasn't been much formal discussion around this issue. In fact, this term should become formalized, with all direct Inuit ancestors back to and including Thule Inuit considered part of the "Inuit tradition"; it's hard to justify not using this term when the people who lived in these sites were Inuit!

However, the use of the term "Paleo-Eskimo" presents a thornier issue. Both the archaeological record and recent studies of ancient DNA indicate that there was little direct interaction between Paleo-Eskimos and Inuit, and that they were distinct populations. The thinking might be that if they were not Inuit, then the use of the term "Eskimo" as the root of Paleo-Eskimo shouldn't matter. As mentioned earlier, there is also a very reasonable desire on the part of archaeologists to be conservative in the naming of traditions - we can't go around randomly changing the names of ancient cultures, or none of us will know what the other is talking about.

The flip side, of course, is that even with minimal contact, Paleo-Eskimos were at least in some conceptual ways the ancestors of Inuit. Inuit have many oral historical accounts of meeting with "Tuniit," who lived in the eastern Arctic when Inuit arrived, and most of these accounts probably refer to the final Paleo-Eskimos, known as Late Dorset. It is also likely that during the brief period of overlap between the final Paleo-Eskimos and the earliest Inuit, Late Dorset passed on a range of knowledge, including where to find important raw materials such as soapstone and meteoritic iron, and perhaps technologies such as the building of snow houses. Regardless, the issue of using "Eskimo" as a root remains problematic to many who do not want to impose this external, potentially pejorative term, on a major Arctic cultural entity (see Hardenberg, 2013 for additional discussion).

With this in mind, a number of alternative terms might be, or have been, proposed, including a broadening of "Arctic Small Tool tradition" to incorporate the entire Paleo-Eskimo span, and variants of "Paleo-Inuit" and "Pre-Inuit." One might also consider referring to this as the "Tuniit" tradition, in line with the Inuit term for those who came before them. All of these 
suggestions have merits and drawbacks, however "Paleo-Inuit" is probably the most elegant, mainly because it is simply a direct translation of "Paleo-Eskimo," substituting Inuit as the root. It also directly reflects the temporal relationship of this tradition to Inuit-with "Paleo" simply meaning "old."

It turns out that the Inuit Circumpolar Council (ICC), the organization representing all Inuit, Inuvialuit, Iñupiat, and Yupik peoples from Greenland to Chukotka, is ahead of us on this issue. ICC Resolution 2010-01 explicitly advocates changing Paleo-Eskimo to "paleo-Inuit," citing a number of factors, but most importantly, "the rights of an indigenous people to self-identify... [and] the rights of indigenous peoples to full realization of their social and cultural identity, their customs and traditions" (ICC, 2010). This is a constructive resolution, meant to help archaeologists come up with a consistent term that does not use the root "Eskimo." I therefore strongly suggest we collectively switch to this term-it makes sense at a fundamental level that we follow the ICC's lead on the naming of Arctic cultural entities. The only small augmentation needed is to use an upper case "P" in Paleo, to match archaeological convention in naming major traditions. Furthermore, I would urge us to agree on a single spelling-Paleo-Inuitrather than toying with alternatives such as Paleoinuit, Palaeo-Inuit, or Palaeoinuit.

This leads, inevitably, to the question of what to call the comparable traditions in the western Arctic, consisting mainly of coastal northwest Alaska and Chukotka. Here, the sequence of archaeological cultures is more complex than the eastern Arctic version, in large part because of more frequent interactions with neighboring Subarctic and Bering Sea peoples. There is also less agreement on how to label these traditions; and the term "Paleo-Eskimo" is used less frequently than in the eastern Arctic, while "Arctic Small Tool tradition" is used more often. My own preference would be simply to use the same terms. Thus, Denbigh Flint Complex, Choris, Norton, and Ipiutak would be considered part of the Paleo-Inuit tradition; and Old Bering Sea, Punuk, Birnirk, and Thule, part of the Inuit tradition. This scheme has the advantage of clearly indicating parallels between the western and eastern Arctic sequences, as well as the elegance of being consistent with the ICC Resolution. It is important to reiterate that the ICC represents all of the peoples of the macro-region, from Chukotka to Greenland, including Yupik and Iñupiat, not just those who currently self-identify as "Inuit." However, issues as fundamental as terminology need to be resolved by consensus, so I wish my Alaskan and Chukotkan colleagues the best of luck if they choose to have this conversation.

In sum, Arctic archaeologists should follow the lead of the Inuit Circumpolar Council. While the use of the term "Inuit" to label the most recent tradition seems obvious, we should also refer to the preceding tradition not as Paleo-Eskimo, but as Paleo-Inuit.

\section{REFERENCES}

Hardenberg, M. 2013. Trends and ontology of artistic practices of the Dorset Culture 800 BC-1300 AD. Doctoral dissertation, Faculty of Humanities, University of Copenhagen.

ICC (Inuit Circumpolar Council). 2010. Inuit Circumpolar Council Resolution 2010-01 on the use of the term Inuit in scientific and other circles.

http://www.inuitcircumpolar.com/-the-use-of-the-term-inuit.html

Steensby, H.P. 1916. An anthropogeographical study of the origin of the Eskimo culture. Meddelelser om Grønland 53(2). Copenhagen: Bianco Lunos Bogtrykkeri.

T. Max Friesen

Department of Anthropology

University of Toronto

Toronto, Ontario M5S 2S2, Canada

max.friesen@utoronto.ca 